\title{
STATINS AND THE RISK FOR CORONARY IN-STENT RESTENOSIS IN DIABETIC PATIENTS
}

\author{
DANIEL NIŢA ${ }^{1 \#}$, MIHAELA IONESCU ${ }^{2}$, LAURA MAZILU $^{2}$, ANDRA IULIA SUCEVEANU $^{2}$, \\ ALICE MUNTEANU ${ }^{1}$, PARIS IONESCU ${ }^{2}$, LILIANA ANA TUŢA ${ }^{2 *}$, FLORIN BUICU ${ }^{3}$, IRINEL \\ RALUCA PAREPA ${ }^{2}$
}

\author{
${ }^{1}$ Army's Centre for Cardiovascular Diseases, Bucharest, Romania \\ 2 "Ovidius" University of Constanța, Faculty of General Medicine, Constanța, Romania \\ 3 “George Emil Palade” University of Medicine, Pharmacy, Science and Technology, Târgu-Mureș, Romania
}

*corresponding author: tutaliliana@yahoo.com

${ }^{\#}$ Authors with equal contribution.

Manuscript received: October 2020

\begin{abstract}
Diabetes mellitus is considered to be an independent risk factor for the progression of coronary artery disease, due to the associated pro-atherosclerotic status, and also an important predictor of poor outcomes after both coronary artery bypass grafting and percutaneous coronary intervention. Even in the contemporary era of newer-generation stents and despite remarkable technological advances, in-stent restenosis is still a major problem. The aim of our study was to identify risk factors for restenosis in the first year after stent deployment in 95 diabetic patients with coronary heart disease. Our results suggest that a larger stent diameter and the use of statins positively influence the risk of in-stent restenosis in the first year after stent implantation. Systemic statin therapy should be considered in all interventional treated diabetic patients, in order to reduce the risk of in-stent restenosis, particularly in high-risk patients.
\end{abstract}

\section{Rezumat}

Diabetul zaharat este considerat a fi un factor de risc independent pentru progresia bolii coronariene ischemice (BCI), datorită statusului pro-aterosclerotic și, de asemenea, un predictor important al prognosticului terapiilor de reperfuzie coronariană. Chiar și în epoca contemporană, a stenturilor de „nouă generație” și în ciuda progreselor tehnologice remarcabile, restenozarea in-stent rămâne o problemă semnificativă. Scopul studiului nostru a fost identificarea factorilor de risc pentru restenoză în primul an după instalarea stentului la un grup de 95 de pacienți diabetici cu BCI. Rezultatele noastre sugerează că diametrul mai mare al stentului și utilizarea statinelor influențează favorabil riscul de restenozare in-stent în primul an după implantare. Terapia sistemică cu statine trebuie luată în considerare la toți pacienții diabetici cu intervenție, pentru a reduce riscul de restenozare in-stent.

Keywords: statins, coronary in-stent restenosis, diabetes mellitus

\section{Introduction}

Diabetes mellitus is considered to be an independent risk factor for coronary artery disease progression due to a pro-atherosclerotic status involving several physiopathological mechanisms [1]. Moreover, patients with diabetes have a significantly higher cardiovascular mortality rate in comparison with the general population [2]. Angiographic studies have indicated that diabetic patients frequently have diffuse vascular injury - with a higher plaque burden, smaller vessel reference diameter, poorly developed collateral circulation, and an increased incidence of multivessel or left main disease [1, 3]. In addition, diabetes is shown to be an important predictor of poor outcomes after both coronary artery bypass grafting and percutaneous coronary intervention $[4,5]$.

Even in the contemporary era of newer-generation stents and despite remarkable technological advances, in-stent restenosis remains a significant problem [6, 7]. In-stent restenosis is angiographically defined as a recurrent stenosis greater than $50 \%$ in the previously treated vessel segment and is due to excessive tissue proliferation by neo-intimal accumulation or newoccurring atherosclerotic process called "neoatherosclerosis" [7-9]. Several clinical, biological, angiographic, procedural or pharmacological parameters have been correlated with the presence or absence of restenosis in the coronary stents [7-12]. The emergence of drugeluting stents (DES) with the concept of stents as local drug delivery platforms aims neointimal hyperplasia, which is the main mechanism of restenosis during the first 12 months post-implantation [9]. This has reduced the need for target vessel revascularization to less than $50 \%$ compared to bare-metal stents (BMS) $[6,9]$.

However, diabetes remains the most robust clinical parameter correlated with clinical and angiographic 
recurrences after percutaneous coronary intervention (PCI) [7, 8]. Hyperglycaemia produces endothelial dysfunction and a persistent proinflammatory status that can exaggerate the neointimal reaction in case of vascular injury, the incidence of restenosis and the need for repeated PCI $[8,13]$.

The aim of the present study was to identify the risk factors for restenosis in the first year after stent implantation in diabetic patients with coronary heart disease. Because our primary objective was to detect the effects of the main pharmacological classes on the risk of restenosis, this study was performed in bare-metal stents, thus eliminating the beneficial effect on smooth muscle cell proliferation and neointimal hyperplasia attributed to the pharmacologically active substance locally released by DES.

\section{Materials and Methods}

We retrospectively analysed PCI data using our interventional database from the Army's Centre for Cardiovascular Diseases from Bucharest, Romania, constituted along more than ten years; we identified 95 patients eligible for the study. The study obtained the approval of the local Ethical Committee.

Inclusion criteria: diabetic patients with "bare metal" stent implantation for coronary artery diseases who suffered an angiographic evaluation within one year following the initial procedure for clinical reasons.

Exclusion criteria: patients with initial sub-optimal post-procedural results, patients with major cardiac events in the first month after implantation, patients with incomplete data acquisition; patients with newly developed coronary lesions.

Coronary angiography was performed in agreement with the standard operating protocols and every lesion was analysed in minimum two orthogonal projections. We obtained the details regarding the length and diameter of the implanted stents from patients' medical records. Definition of in-stent restenosis according to angiographic criteria is recurrent restenosis with percentage diameter $\geq 50 \%$ within stent level or within its 5-mm proximal and distal edges.

We retrospectively collected data related to the initial angiography (indication for invasive evaluation, coronary anatomy, location, complexity and morphological characteristics of coronary lesions), subsequent interventional treatment (number of treated lesions and vessels, number and dimensions of implanted stents) as well as clinical and biological data relevant to the study. Thus, several angiographic parameters were evaluated as they were defined in the literature $[14,15]$. Statistical analysis

For the statistical analysis IBM SPSS version 26 was used. Univariate data analysis was performed using chi square tests (Pearson Chi square, Fisher Exact Test) for categorical variables and student $t$ test (normal distribution) for continuous ones. Multivariate analysis was performed using logistic regression (dichotomous dependent variable, continuous and categorical independent variables). The graphical representation of the data was realized through graphical columns, ROC and Forest. Statistically significant $\mathrm{p}$ value was $\mathrm{p} \leq 0.05$.

\section{Results and Discussion}

We identified 95 diabetic patients eligible for the study from which 82 patients $(86.3 \%)$ with at least one in-stent restenosis, and 13 patients $(13.7 \%)$ without in-stent restenosis. The mean period of time from the first procedure to the invasive re-evaluation was $220.6 \pm 17.2$ days for the restenosis group, respectively $277.5 \pm 10.1$ days for the group without restenosis. Baseline features of both studied groups are shown in Table I.

Table I

Baseline characteristics for the patients groups

\begin{tabular}{|lcccc|}
\hline & $\begin{array}{c}\text { Restenosis } \\
(\mathbf{n = 8 2})\end{array}$ & $\begin{array}{c}\text { No restenosis } \\
(\mathbf{n = 1 3})\end{array}$ & $\begin{array}{c}\chi^{2 /} \\
\mathbf{t} \text { test }\end{array}$ & p value \\
\hline Age & $58(\mathrm{IQR}=13)$ & $56(\mathrm{IQR}=17)$ & 1.374 & 0.241 \\
\hline Sex & & & & \\
\hline Male & $41(50 \%)$ & $8(61.5 \%)$ & 0.598 & 0.439 \\
Female & $41(50 \%)$ & $5(38.5 \%)$ & & \\
\hline Clinical/paraclinical data & & & - & 0.535 \\
\hline High blood pressure & $54(65.9 \%)$ & $7(53.8 \%)$ & - & 0.990 \\
Hypercholesterolemia & $52(63.4 \%)$ & $8(61.5 \%)$ & - & 0.207 \\
Smoking & $23(28 \%)$ & $6(46.2 \%)$ & - & 0.120 \\
Peripheral arteries disease & $25(30.5 \%)$ & $7(53.8 \%)$ & - & 0.529 \\
Chronic kidney disease & $4(4.9 \%)$ & $1(7.7 \%)$ & & \\
\hline Initial PCI indication & & & & \\
\hline Acute coronary syndrome & $41(50 \%)$ & $6(46.2 \%)$ & 0.031 & 0.860 \\
Stable angina & $31(37.8 \%)$ & $4(30.8 \%)$ & - & 0.762 \\
Silent cardiac ischemia & $10(12.2 \%)$ & $3(23.1 \%)$ & - & 0.378 \\
\hline Diabetes treatment & & & & \\
\hline Oral hypoglycaemic medication & $64(78 \%)$ & $8(61.55)$ & - & 0.293 \\
Insulin & $10(12.2 \%)$ & $2(15.4 \%)$ & - & 0.667 \\
\hline
\end{tabular}


FARMACIA, 2021, Vol. 69, 3

\begin{tabular}{|c|c|c|c|c|}
\hline & $\begin{array}{c}\text { Restenosis } \\
(\mathbf{n}=\mathbf{8 2})\end{array}$ & $\begin{array}{c}\text { No restenosis } \\
(\mathrm{n}=13)\end{array}$ & $\begin{array}{c}\chi^{2 /} \\
\text { t test }\end{array}$ & p value \\
\hline \multicolumn{5}{|l|}{ Other treatments } \\
\hline Beta-blockers & $72(87.8 \%)$ & $9(69.2 \%)$ & - & 0.097 \\
\hline Calcium channel blockers & $10(12.2 \%)$ & $3(23.1 \%)$ & - & 0.378 \\
\hline Diuretics & $8(9.8 \%)$ & $4(30.8 \%)$ & - & 0.057 \\
\hline ACEI/ARB & $54(65.9 \%)$ & $8(61.5 \%)$ & - & 0.763 \\
\hline Statins & $49(59.8 \%)$ & $12(92.3 \%)$ & - & 0.028 \\
\hline Aspirin & $66(80.5 \%)$ & $11(84.6 \%)$ & - & 0.999 \\
\hline Clopidogrel & $65(79.3 \%)$ & $11(84.6 \%)$ & - & 0.999 \\
\hline Nitrates & $10(12.2 \%)$ & $2(15.4 \%)$ & - & 0.999 \\
\hline eGFR CKD-EPI $\left(\mathrm{mL} / \mathrm{min} / \mathrm{m}^{2}\right)$ & $69.9(\mathrm{IQR}=13)$ & $78(\mathrm{IQR}=26.7)$ & 0.115 & 0.734 \\
\hline BMI $\left(\mathrm{Kg} / \mathrm{m}^{2}\right)$ & $30.4(\mathrm{IQR}=4.5)$ & $29.9(\mathrm{IQR}=4.2)$ & 0.479 & 0.489 \\
\hline HbA1c & $7.4(\mathrm{IQR}=0.8)$ & $7.1(\mathrm{IQR}=0.7)$ & 2.108 & 0.147 \\
\hline
\end{tabular}

$\%$ expressed in restenosis vs. no-restenosis group, $\mathrm{ACEI}=$ angiotensin converting enzyme inhibitors; $\mathrm{ARB}=$ angiotensin receptors blockers

There was a higher percentage, however statistically insignificant, of women in the group with in-stent restenosis ( $50 \%$ vs. $38.5 \%, \mathrm{p}=0.439)$. Also, risk factors for coronary heart disease (hypertension, dyslipidaemia and smoking) did not differ significantly between the two groups. We observed, instead, a higher percentage of patients undergoing statin treatment in the norestenosis group (92.3\% vs. 59.8\%), a statistically significant result $(\mathrm{p}=0.028)$. We mention that all our patients received statins at high doses: atorvastatin $40-80 \mathrm{mg} /$ day or rosuvastatin $20-40 \mathrm{mg}$ /day.
The oral hypoglycaemic treatment included metformin hydrochloride (1000 - $2000 \mathrm{mg} /$ day) and/or gliclazide (60 - $120 \mathrm{mg} /$ day).

A total of 154 stented lesions were analysed (136 in the group with restenosis, 18 in the group without restenosis) of which $110(71.4 \%)$ presented angiographic criteria for restenosis and 44 (28.6\%) stents without restenosis. Table II shows the baseline characteristics per lesion.

Table II

Baseline characteristics per lesion

\begin{tabular}{|lcccc|}
\hline & $\begin{array}{c}\text { Restenosis } \\
(\mathbf{n = 1 1 0})\end{array}$ & $\begin{array}{c}\text { No restenosis } \\
(\mathbf{n = 4 4 )}\end{array}$ & $\chi^{\mathbf{2}}$ & p value \\
\hline Sex & & & & \\
\hline Male & $73(66.4 \%)$ & $23(52.3 \%)$ & 2.658 & 0.103 \\
Female & $37(33.6 \%)$ & $21(47.7 \%)$ & & \\
\hline Clinical/paraclinical data & & & \\
\hline High blood pressure & $73(66.4 \%)$ & $32(72.7 \%)$ & 0.587 & 0.444 \\
Hypercholesterolemia & $72(65.5 \%)$ & $33(75 \%)$ & 1.320 & 0.251 \\
Smoking & $39(35.5 \%)$ & $19(43.2 \%)$ & 0.799 & 0.371 \\
Peripheral arteries disease & $41(37.3 \%)$ & $18(40.9 \%)$ & 0.176 & 0.675 \\
Chronic kidney disease & $5(4.5 \%)$ & $2(4.5 \%)$ & - & 1.000 \\
\hline Initial PCI indication & & & & \\
\hline Acute coronary syndrome & $60(54.5 \%)$ & $25(56.8 \%)$ & 0.066 & 0.798 \\
Stable angina & $36(32.7 \%)$ & $16(36.4 \%)$ & 0.186 & 0.666 \\
Silent cardiac ischemia & $14(12.7 \%)$ & $3(6.8 \%)$ & - & 0.398 \\
\hline Diabetes treatment & \multicolumn{5}{c}{} & \\
\hline Oral hypoglycaemic medication & $90(81.8 \%)$ & $32(72.7 \%)$ & 1.578 & 0.209 \\
Insulin & $10(9.1 \%)$ & $3(6.8 \%)$ & - & 0.759 \\
\hline Other treatments & & & \\
\hline Beta-blockers & $94(85.5 \%)$ & $36(81.1 \%)$ & 0.316 & 0.574 \\
Calcium channel blockers & $16(14.5 \%)$ & $7(15.9 \%)$ & 0.046 & 0.830 \\
Diuretics & $12(10.9 \%)$ & $10(22.7 \%)$ & 3.585 & 0.058 \\
ACEI/ARB & $79(71.8 \%)$ & $35(79.5 \%)$ & 0.976 & 0.323 \\
Statins & $\mathbf{5 6}(\mathbf{5 0 . 9 \% )}$ & $\mathbf{3 4}(\mathbf{7 7 . 3 \% )}$ & $\mathbf{8 . 9 9 4}$ & $\mathbf{0 . 0 0 3}$ \\
Aspirin & $83(75.5 \%)$ & $36(81.8 \%)$ & 0.725 & 0.395 \\
Clopidogrel & $92(83.6 \%)$ & $40(90.9 \%)$ & 1.358 & 0.244 \\
Nitrates & $15(13.6 \%)$ & $8(18.2 \%)$ & 0.511 & 0.475 \\
\hline
\end{tabular}

$\%$ expressed in groups (restenosis $v s$. no restenosis), $\mathrm{ACEI}=$ angiotensin converting enzyme inhibitors; $\mathrm{ARB}=$ angiotensin receptors blockers

We observed that there were no statistically significant differences between the two groups regarding the treatment with insulin, oral hypoglycaemic medication, beta-blockers, ACEIs/ARBs, diuretics, calcium channel blockers or nitrates. Although there was a more frequent association of permeable stents with aspirin $(81.8 \%$ 
vs. $75.5 \%)$ or clopidogrel $(90.9 \%$ vs. $83.6 \%)$, this correlation was not significant $(\mathrm{p}=0.395$ and $\mathrm{p}=$ 0.244 , respectively). On the contrary, there was a significant correlation between statin treatment and stents without restenosis $(\mathrm{p}=0.003$, OR 0.305, 95\% CI 0.137-0.677) (Figure 1).
Regarding angiographic characteristics among the two studied groups (Table III), lesion length $>28$ $\mathrm{mm}$ were correlated with restenosis $(\mathrm{p}=0.002$, OR $6.114,95 \%$ CI $1.769-21.129)$ and diameter $\geq 3.5$ $\mathrm{mm}$ with stents without restenosis $(\mathrm{p}=0.014$, OR $0.365,95 \%$ CI $0.160-0.834)$.

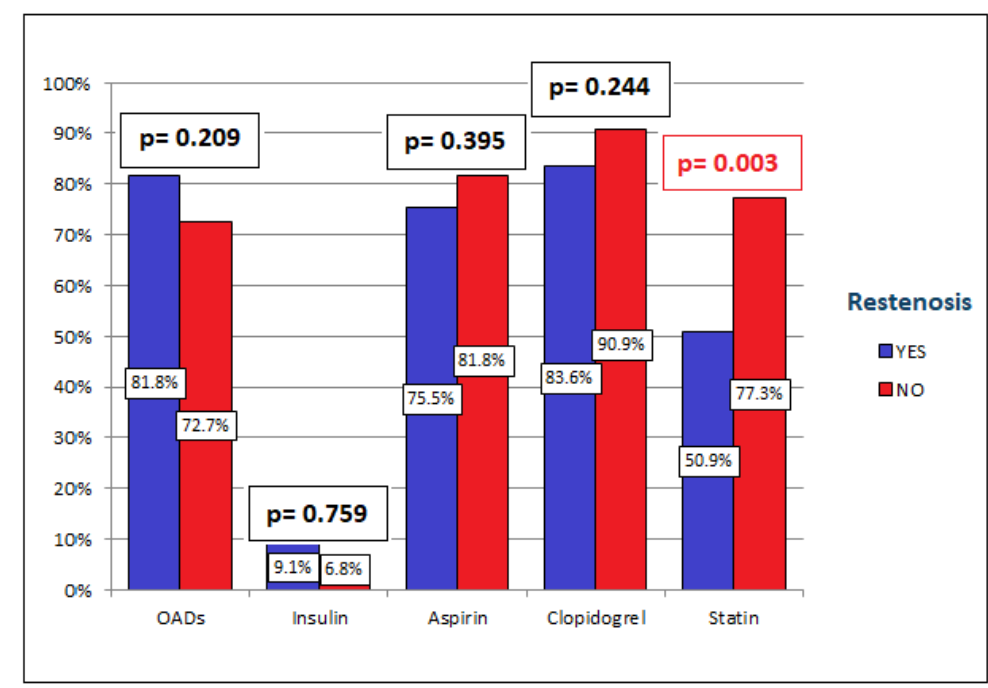

Figure 1.

Stents distribution according to the hypoglycaemia/antiplatelet/statin treatment and restenosis/no-restenosis (OADs $=$ oral antidiabetic drugs)

Table III

Baseline angiographic characteristics per lesion

\begin{tabular}{|c|c|c|c|c|}
\hline & $\begin{array}{c}\text { Restenosis } \\
(n=110)\end{array}$ & $\begin{array}{l}\text { No restenosis } \\
\quad(n=44)\end{array}$ & $\chi^{2}$ & $p$ value \\
\hline \multicolumn{5}{|l|}{ Stent location } \\
\hline LAD & $51(46.4 \%)$ & $22(50 \%)$ & 0.167 & 0.683 \\
\hline LCX & $24(21.8 \%)$ & $10(22.7 \%)$ & 0.015 & 0.902 \\
\hline $\mathrm{RCA}$ & $35(31.8 \%)$ & $12(27.3 \%)$ & 0.306 & 0.580 \\
\hline \multicolumn{5}{|l|}{ Stent diameter } \\
\hline$\leq 2.5 \mathrm{~mm}$ & $46(41.8 \%)$ & $13(29.5 \%)$ & 2.003 & 0.157 \\
\hline $2.5-3.5 \mathrm{~mm}$ & $48(43.6 \%)$ & $17(38.6 \%)$ & 0.322 & 0.570 \\
\hline$\geq 3.5 \mathrm{~mm}$ & $16(14.5 \%)$ & $14(31.8 \%)$ & 5.978 & 0.014 \\
\hline \multicolumn{5}{|l|}{ Stented length } \\
\hline$\leq 15 \mathrm{~mm}$ & $26(23.6 \%)$ & $15(34.1 \%)$ & 1.758 & 0.185 \\
\hline $15-28 \mathrm{~mm}$ & $50(45.5 \%)$ & $26(59.1 \%)$ & 2.338 & 0.126 \\
\hline$>28 \mathrm{~mm}$ & $34(30.9 \%)$ & $3(6.8 \%)$ & 9.993 & 0.002 \\
\hline \multicolumn{5}{|l|}{ Lesion type } \\
\hline Type A + B & $60(54.5 \%)$ & $31(70.5 \%)$ & & 0070 \\
\hline Type C (ACC/AHA) & $50(45.5 \%)$ & $13(29.5 \%)$ & 3.291 & $0.0 \%$ \\
\hline Ostial lesion & $6(5.5 \%)$ & $1(2.3 \%)$ & - & 0.674 \\
\hline Calcification & $18(16.4 \%)$ & $5(11.4 \%)$ & 0.618 & 0.432 \\
\hline Chronic total occlusion & $12(10.9 \%)$ & $3(6.8 \%)$ & - & 0.557 \\
\hline Thrombus & $9(8.2 \%)$ & $2(4.5 \%)$ & - & 0.730 \\
\hline Bifurcation & $2(1.8 \%)$ & $0(0 \%)$ & - & - \\
\hline
\end{tabular}

$\mathrm{LAD}=$ left anterior descendant artery; $\mathrm{LCx}=$ left circumflex artery; $\mathrm{RCA}=$ right coronary artery

Table IV

Corelation between stented length $>28 \mathrm{~mm}$, stent diameter and in-stent restenosis

\begin{tabular}{|l|c|c|c|c|}
\hline & $\begin{array}{c}\text { Restenosis } \\
(\mathbf{n}=\mathbf{1 1 0})\end{array}$ & $\begin{array}{c}\text { No restenosis } \\
(\mathbf{n}=\mathbf{4 4})\end{array}$ & p value & OR [CI 95\%] \\
\hline$\leq \mathbf{2 . 5} \mathbf{~ m m} />\mathbf{2 8} \mathbf{~ m m}$ & $\mathbf{1 5}(\mathbf{1 3 . 6 \%})$ & $\mathbf{1}(\mathbf{2 . 3 \%})$ & $\mathbf{0 . 0 4 1}$ & {$[\mathbf{0 . 7 3 5}-\mathbf{3 3 . 7 9 8}]$} \\
\hline $\mathbf{2 . 5}-\mathbf{3 . 5} \mathbf{~ m m} />\mathbf{2 8 ~ \mathbf { ~ m m }}$ & $\mathbf{1 6}(\mathbf{1 4 . 5 \%})$ & $\mathbf{1}(\mathbf{2 . 3 \%})$ & $\mathbf{0 . 0 4 2}$ & {$[\mathbf{0 . 9 4 0}-\mathbf{5 6 . 9 8 3}]$} \\
\hline$\geq 3.5 \mathrm{~mm} />28 \mathrm{~mm}$ & $3(2.7 \%)$ & $1(2.3 \%)$ & 0.999 & {$[0.122-11.193]$} \\
\hline
\end{tabular}




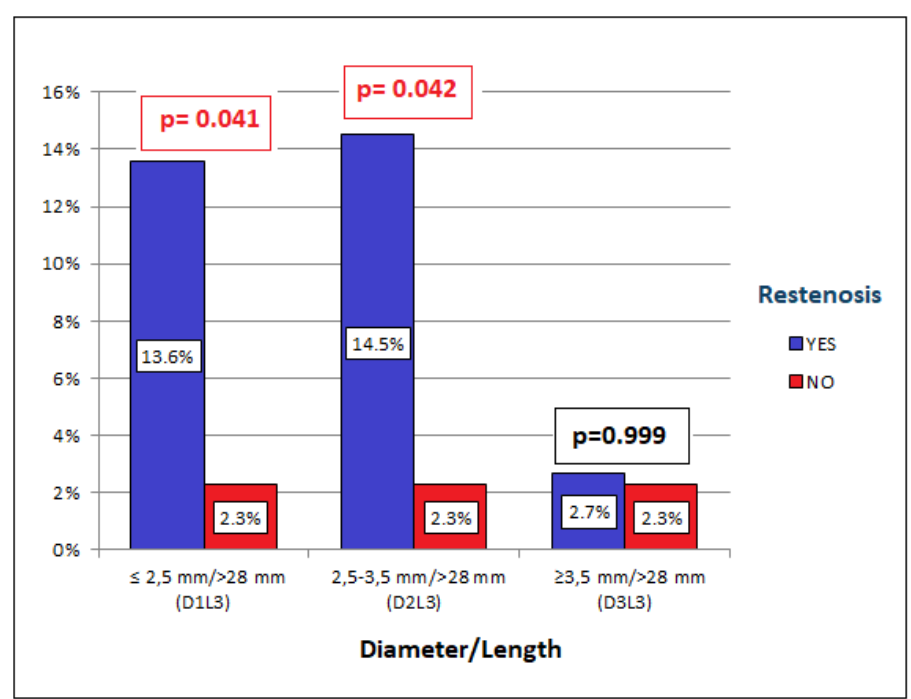

Figure 2.

Stents distribution based on stent diameter/ length $>28 \mathrm{~mm}$ and restenosis/no-restenosis

We also studied the relationship between stented length $>28 \mathrm{~mm}$, stent diameter and the presence or absence of in-stent restenosis. Thus, we noticed a significantly higher proportion of stents with length $>28 \mathrm{~mm}$ and diameter $\leq 2.5 \mathrm{~mm}$ or $2.5-3.5 \mathrm{~mm}$ in the restenosis group $(13.6 \%$ vs. $2.3 \%, \mathrm{p}=0.041$, respectively $14.5 \%$ vs. $2.3 \%, \mathrm{p}=0.042$ ) (Table IV, Figure 2).

All the 3 parameters with statistical significance resulting from the univariate analysis (stent diameter

$\geq 3.5 \mathrm{~mm}$, stented length $>28 \mathrm{~mm}$ and statin treatment) were introduced in the logistic regression model. All 3 parameters retain their statistical significance (Table V).

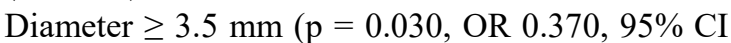
$0.151-0.911)$ and statins $(\mathrm{p}=0.002$, OR 0.271 , $95 \%$ CI $0.117-0.630)$ reduce the probability of restenosis while stented length $>28 \mathrm{~mm}(\mathrm{p}=0.006$, OR 5. 944, 95\% CI 1.669 - 21.164) favours restenosis (Figure 3).

Table V

Independent risk factors for restenosis (multivariate analysis)

\begin{tabular}{|lllllll}
\hline & Estimated coefficient & & & & \multicolumn{2}{c}{$[\mathbf{9 5 \%}$ CI] } \\
& & Test Wald (df) & p value & Odd ratio & Lower & Upper \\
\hline $\mathbf{2 3 . 5} \mathbf{~ m m}$ & -0.994 & $4.682(1)$ & 0.030 & 0.370 & 0.151 & 0.911 \\
\hline $\mathbf{2 8} \mathbf{~ m m}$ & 1.789 & $7.566(1)$ & 0.006 & 5.944 & 1.669 & 21.164 \\
\hline Statins & -1.305 & $9.194(1)$ & 0.002 & 0.271 & 0.117 & 0.630 \\
\hline
\end{tabular}

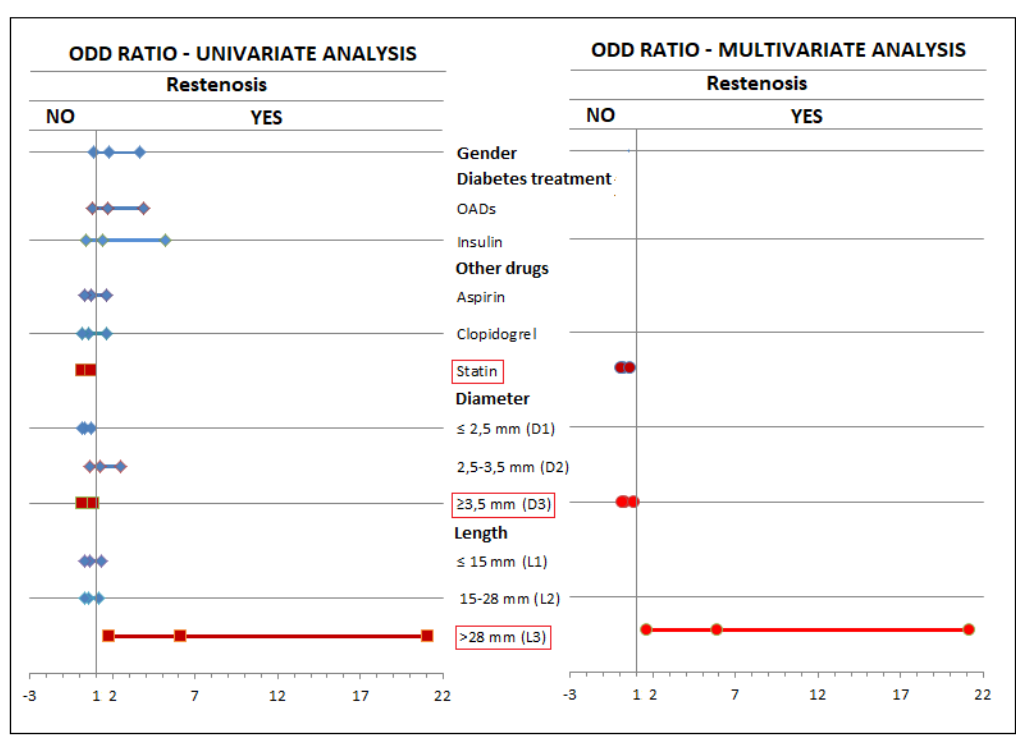

Figure 3.

Risk factors for restenosis (uni- and multivariate analysis) 
The predictive power of the logistic regression model was also evaluated by using the analysis of the receiver operating characteristic (ROC) curve which showed an area-under-curve (AUC) of 0.749 (good predictability) (Figure 4).

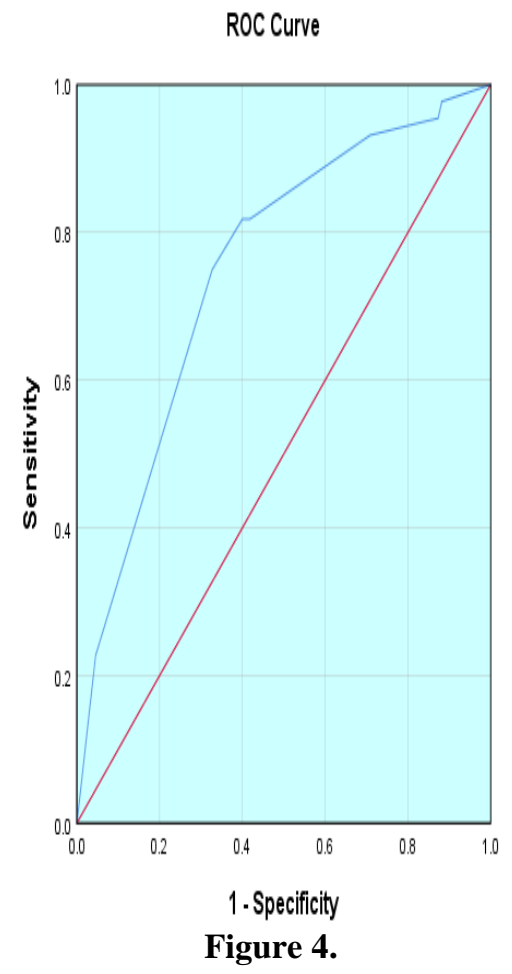

ROC curve for the logistic regression model

Coronary heart disease displays some gender differences, regarding clinical manifestations, outcome and pharmacological treatment, in particular regarding the statin therapy [16]. Even though without statistical significance, there was a higher percentage of women in the group with in-stent restenosis (50\% vs. 38.5\%, $\mathrm{p}=0.439$ ). Studies show that women have a poor adherence to statin treatment because of the side effects, so that they usually receive a lower dose of medication [17].

Most elderly patients (more than 60 - 65 years old, according to World Health Organization) with dyslipidaemia are at increased risk of coronary events and stroke, so the benefits of statins outweigh their unexpected secondary effects. However, treatment with high doses of statins in elderly needs close monitoring for safety [18].

Coronary lesions in diabetic patients are characterized by a diffuse form of atherosclerosis - generating longer, more complex lesions, with an underlying biological status that promotes neointimal hyperplasia and high rates of subsequent restenosis after stent deployment [19-21].

It has been suggested that the duration of diabetes may be a cardiovascular disease risk factor. In our study the mean duration of diabetes was 8.6 years, ranging from 1 to 22 years.

Moreover, interventional coronary revascularization is characterized by an increased incidence of in-stent restenosis and the risk of major cardiac events compared to non-diabetic patients [20, 22]. For example, in a series of patients enrolled in 16 studies, angiographic recurrence at 6 months was found in $31.1 \%$ of patients with diabetes and only in $20.6 \%$ of those without diabetes $(p<0.001)$ [22].

Several studies have reported that smaller vessel reference diameter, smaller minimal luminal diameter after stenting and greater stented length are important predictors of stent restenosis in diabetic patient [2224]. Moreover, the progressive increase of stented length or the progressive reduction of the postintervention luminal diameter progressively increases the subsequent risk of angiographic recurrence [23]. There are several explanations for this phenomenon. First, the extent of vascular injury and subsequent neo-intimal response correlates with stent length [8, 25]. Second, for a certain degree of neo-intimate accumulation, the possibility of a reduction over $50 \%$ of the luminal diameter is dependent on that of the implanted stent [26]. Similarly, in our study, the stent length $>28 \mathrm{~mm}$ is an independent predictor of restenosis in the coronary stent. When we analysed the stent length $>28 \mathrm{~mm}$ in combination with the stent diameter we found a significant association with stent restenosis in diameters $<3.5 \mathrm{~mm}$. In contrast, diameter $\geq$ $3.5 \mathrm{~mm}$ represent a protective factor and are significantly correlated with the presence of permeable stents in diabetic patients. This is also in accordance with the early observations which suggest that in large vessels (> $3.0 \mathrm{~mm}$ diameter) the rate of in-stent restenosis is not significantly different between diabetic and nondiabetic patients [27].

It is proven that premature discontinuation of double antiplatelet therapy is associated with an increased risk of major cardiac events and of stent thrombosis $[9,28]$. In our study compliance with double antiplatelet therapy was good, with no statistically significant differences between patients with or without stent angiographic restenosis. Information on the possible protective effect of anti-diabetic medication on stent restenosis is inconsistent and inconclusive [11, 29-32]. Several studies have suggested that some oral antidiabetics, such as thiazolidinediones, lower the risk of stent restenosis and major post-procedural cardiac events $[11,29]$. On the other hand, although preclinical studies have indicated that insulin administration reduces intimal hyperplasia, the incidence of in-stent restenosis does not appear to be influenced when comparing insulin therapy with usual care with oral hypoglycaemic agents [30]. In our study we did not find a significant association between the antidiabetic medication and the presence or absence of in-stent restenosis. 
FARMACIA, 2021, Vol. 69, 3

According to our results, the only class of drugs that favourably influences in-stent restenosis is represented by statins. This is in accordance with several previous studies showing that statins have many attributes that can reduce the development of post-angioplasty restenosis [10, 33-39]. Moreover, data provided by the Lescol Intervention Prevention Study (LIPS) sub-study show that statins reduce the impact of diabetes on long-term outcome after coronary intervention and also decrease the risk of major adverse cardiovascular events in diabetic patients by over $50 \%$ [33]. The efficacity of statins is mainly due to their pleiotropic effects rather than their lipid-lowering success [34, 40, 41]. In addition to lowering cholesterol, they have many other effects (anti-inflammatory, antithrombotic, antioxidant, lowering the level of C-reactive protein, antimitotic - inhibiting the proliferation of smooth muscle cells, increasing the synthesis of nitric oxide and stimulating the expression and activity of endothelial nitric oxide synthase) [10]. In diabetic patients, high intensity statin therapy increases endothelial progenitor cell levels and decreases in-stent neointima volume [36]. Moreover, the administration of statins before the coronary angioplasty procedure is associated with a reduction in myocardial necrosis peri- and post-percutaneous transluminal coronary angiography (PTCA) and also decreases the need for repeated revascularization [38]. In addition, there is evidence that statin-releasing stents inhibit the restenosis process in animal models [39].

These observations are supported by our study results, which conclude that statins represent an independent factor for stents' permeability first year post-implantation in diabetic patient.

The main limitation of our research is its retrospective design, being a "real world", not a randomized study; also, data related to procedural or genetic factors, proven to be related to in-stent restenosis were not been evaluated.

\section{Conclusions}

In-stent restenosis in patients with diabetes remains a problem still incompletely solved, even in the era of new generation stents. Our results suggest that larger stent diameter and the use of statins have a positive impact on the risk of in-stent restenosis in the first 12-months after stent implantation - when the main restenosis mechanism is represented by neointimal hyperplasia. Systemic statins therapy should be considered in all interventional treated diabetic patients, in order to decrease the risk of in-stent restenosis and athero-sclerotic plaque progression, especially in those with multiple risk factors. Further and larger studies will be useful, regarding the potential additive effect of statins to the antiproliferative impact of drug-eluting stents.

\section{Conflict of interest}

The authors declare no conflict of interest.

\section{References}

1. Cariou B, Bonnevie L, Mayaudon H, Dupuy O, Ceccaldi B, Bauduceau B, Angiographic characteristics of coronary artery disease in diabetic patients compared with matched non-diabetic subjects. Diabetes Nutr Metab., 2000; 13(3): 134-141.

2. Norhammar A, Diabetes and cardiovascular mortality: the impact of sex. Lancet Diabetes Endocrinol., 2018; 6(7): 517-519.

3. Morgan KP, Kapur A, Beatt KJ, Anatomy of coronary disease in diabetic patients: an explanation for poorer outcomes after percutaneous coronary intervention and potential target for intervention. Heart, 2004; 90(7): 732-738.

4. Fanari Z, Weiss SA, Zhang W, Sonnad SS, Weintraub WS, Meta-analysis of three randomized controlled trials comparing coronary artery bypass grafting with percutaneous coronary intervention using drug-eluting stenting in patients with diabetes. Interact Cardiovasc Thorac Surg., 2014; 19(6): 1002-1007.

5. Hakeem A, Garg N, Bhatti S, Rajpurohit N, Ahmed Z, Uretsky BF, Effectiveness of percutaneous coronary intervention with drug-eluting stents compared with bypass surgery in diabetics with multivessel coronary disease: comprehensive systematic review and metaanalysis of randomized clinical data. J Am Heart Assoc., 2013; 2(4): e000354: 1-11.

6. Piccolo R, Bonaa KH, Efthimiou O, Varenne O, Baldo A, Urban P, Kaiser C, Remkes W, Räber L, de Belder A, van 't Hof AWJ, Stankovic G, Lemos PA, Wilsgaard T, Reifart J, Rodriguez AE, Ribeiro EE, Serruys PWJC, Abizaid A, Sabaté M, Byrne RA, de la Torre Hernandez JM, Wijns W, Jüni P, Windecker $\mathrm{S}$, Valgimigli M, Drug-eluting or bare-metal stents for percutaneous coronary intervention: a systematic review and individual patient data meta-analysis of randomised clinical trials. Lancet, 2019; 393(10190): 2503-2510.

7. Dangas GD, Claessen BE, Caixeta A, Sanidas EA, Mintz GS, Mehran R, In-stent restenosis in the drugeluting stent era. J Am Coll Cardiol., 2010; 56(23): 1897-1907.

8. Jukema JW, Verschuren JJ, Ahmed TA, Quax PH, Restenosis after PCI. Part 1: pathophysiology and risk factors. Nat Rev Cardiol., 2011; 9(1): 53-62.

9. Byrne RA, Joner M, Kastrati A, Stent thrombosis and restenosis: what have we learned and where are we going? The Andreas Grüntzig Lecture ESC 2014. Eur Heart J., 2015; 36(47): 3320-3331.

10. Prasad K, Do statins have a role in reduction/ prevention of post-PCI restenosis?. Cardiovasc Ther., 2013; 31(1): 12-26.

11. Patel D, Walitt B, Lindsay J, Wilensky RL, Role of pioglitazone in the prevention of restenosis and need for revascularization after bare-metal stent implantation: a meta-analysis. JACC Cardiovasc Interv., 2011; 4(3): 353-360.

12. Deftereos S, Giannopoulos G, Raisakis K, Kossyvakis C, Kaoukis A, Panagopoulou V, Driva M, Hahalis G, Pyrgakis V, Alexopoulos D, Manolis AS, Stefanadis C, 
Cleman MW, Colchicine treatment for the prevention of bare-metal stent restenosis in diabetic patients. $J$ Am Coll Cardiol., 2013; 61(16): 1679-1685.

13. Aronson D, Edelman ER, Revascularization for coronary artery disease in diabetes mellitus: angioplasty, stents and coronary artery bypass grafting. Rev Endocr Metab Disord., 2010; 11(1): 75-86.

14. Sianos G, Morel MA, Kappetein AP, Morice MC, Colombo A, Dawkins K, van den Brand M, Van Dyck N, Russell ME, Mohr FW, Serruys PW, The SYNTAX Score: an angiographic tool grading the complexity of coronary artery disease. EuroIntervention, 2005; 1(2): 219-227.

15. Ryan TJ, Faxon DP, Gunnar RM, Kennedy JW, King SB $3^{\text {rd }}$, Loop FD, Peterson KL, Reeves TJ, Williams DO, Winters WLJr, Fish C, DeSanctis RW, Dodge HT, Reeves TJ, Weinberg L, Guidelines for percutaneous transluminal coronary angioplasty. A report of the American College of Cardiology/American Heart Association Task Force on Assessment of Diagnostic and Therapeutic Cardiovascular Procedures (Subcommittee on Percutaneous Transluminal Coronary Angioplasty). Circulation, 1988; 78(2): 486-502.

16. Norris CM, Yip CYY, Nerenberg KA, Clavel MA, Pacheco C, Foulds HJA, Hardy M, Gonsalves CA, Jaffer S, Parry M, Colella TJF, Dhukai A, Grewal J, Price JAD, Levinsson ALE, Hart D, Harvey PJ, Van Spall HGC, Sarfi H, Sedlak TL, Ahmed SB, Baer C, Coutinho T, Edwards JD, Green CR, Kirkham AA, Srivaratharajah K, Dumanski S, Keeping-Burke L, Lappa N, Reid RD, Robert H, Smith G, Martin-Rhee M, Mulvagh SL. State of the Science in Women's Cardiovascular Disease: A Canadian Perspective on the Influence of Sex and Gender. J Am Heart Assoc., 2020; 9(4): e015634: 1-27.

17. Gheorghe G, Toth PP, Bungau S, Behl T, Ilie M, Pantea Stoian A, Bratu OG, Bacalbasa N, Rus M, Diaconu CC, Cardiovascular Risk and Statin Therapy Considerations in Women. Diagnostics, 2020; 10(7): 483: 1-19.

18. Horodinschi RN, Stanescu AMA, Bratu OG, Pantea Stoian A, Radavoi DG, Diaconu CC, Treatment with Statins in Elderly Patients. Medicina, 2019; 55(11): 721: 1-11.

19. D'Souza A, Hussain M, Howarth FC, Woods NM, Bidasee K, Singh J, Pathogenesis and pathophysiology of accelerated atherosclerosis in the diabetic heart. Mol Cell Biochem., 2009; 331(1-2): 89-116.

20. Armstrong EJ, Waltenberger J, Rogers JH, Percutaneous coronary intervention in patients with diabetes: current concepts and future directions. J Diabetes Sci Technol., 2014; 8(3): 581-589.

21. Zălar DM, Pop C, Buzdugan E, Todea D, Mogoșan CI, The atherosclerosis-inflammation relationship - a pathophysiological approach. Farmacia, 2019; 67(6): 941-947.

22. West NE, Ruygrok PN, Disco CM, Webster MW, Lindeboom WK, O'Neill WW, Mercado NF, Serruys $\mathrm{PW}$, Clinical and angiographic predictors of restenosis after stent deployment in diabetic patients. Circulation, 2004; 109(7): 867-873.

23. Hong SJ, Kim MH, Ahn TH, Ahn YK, Bae JH, Shim WJ, Ro YM, Lim DS, Multiple predictors of coronary restenosis after drug-eluting stent implantation in patients with diabetes. Heart, 2006; 92(8): 11191124.

24. Mazeika P, Prasad N, Bui S, Seidelin PH, Predictors of angiographic restenosis after coronary intervention in patients with diabetes mellitus. Am Heart J., 2003; 145(6): 1013-1021.

25. Mauri L, O'Malley AJ, Cutlip DE, Ho KK, Popma JJ, Chauhan MS, Baim DS, Cohen DJ, Kuntz RE, Effects of stent length and lesion length on coronary restenosis. Am J Cardiol., 2004; 93(11): 1340-1346.

26. Elezi S, Dibra A, Mehilli J, Pache J, Wessely R, Schömig A, Kastrati A, Vessel size and outcome after coronary drug-eluting stent placement: results from a large cohort of patients treated with sirolimusor paclitaxel-eluting stents. J Am Coll Cardiol., 2006; 48(7): 1304-1309.

27. Süselbeck T, Latsch A, Siri H, Gonska B, Poerner T, Pfleger S, Schumacher B, Borggrefe M, Haase $\mathrm{KK}$, Role of vessel size as a predictor for the occurrence of in-stent restenosis in patients with diabetes mellitus. Am J Cardiol., 2001; 88(3): 243-247.

28. Torrado J, Buckley L, Durán A, Trujillo P, Toldo S, Valle Raleigh J, Abbate A, Biondi-Zoccai G, Guzmán LA, Restenosis, Stent Thrombosis, and Bleeding Complications: Navigating Between Scylla and Charybdis. J Am Coll Cardiol., 2018; 71(15): 16761695.

29. Zhou X, Chen S, Zhu M, Hua J, Dai J, Xu X, Qiu Y, Mao W, Different Effects of Thiazolidinediones on In-Stent Restenosis and Target Lesion Revascularization after PCI: A Meta-Analysis of Randomized Controlled Trials. Sci Rep., 2017; 7(1): 14464: 1-8.

30. Natarajan MK, Strauss BH, Rokoss M, Buller CE, Mancini GB, Xie C, Sheth TN, Goodhart D, Cohen EA, Seidelin P, Harper W, Randomized trial of insulin versus usual care in reducing restenosis after coronary intervention in patients with diabetes. The STent Restenosis And Metabolism (STREAM) study. Cardiovasc Revasc Med., 2012; 13(2): 95-100.

31. Guerra E, Byrne RA, Kastrati A, Pharmacological inhibition of coronary restenosis: systemic and local approaches. Expert Opin Pharmacother, 2014; 15(15): 2155-2171.

32. Manolis AA, Manolis TA, Manolis AS, Cardiovascular Safety of Antihyperglycemic Agents: "Do Good or Do No Harm". Drugs, 2018; 78(15): 1567-1592.

33. Arampatzis CA, Goedhart D, Serruys PW, Saia F, Lemos PA, de Feyter P, Fluvastatin reduces the impact of diabetes on long-term outcome after coronary intervention--a Lescol Intervention Prevention Study (LIPS) substudy. Am Heart J., 2005; 149(2): 329-335.

34. Kamishirado H, Inoue T, Sakuma M, Tsuda T, Hayashi $\mathrm{T}$, Takayanagi K, Node K, Effects of statins on restenosis after coronary stent implantation. Angiology, 2007; 58(1): 55-60.

35. Yagi S, Kondo D, Ise T, Fukuda D, Yamaguchi K, Wakatsuki T, Kawabata Y, Ito H, Saijo Y, Seno H, Sutou K, Ueno R, Todoroki T, Kusunose K, Matsuura T, Tobiume T, Yamada H, Soeki T, Shimabukuro M, Aihara KI, Akaike M, Association of Decreased Docosahexaenoic Acid Level After Statin Therapy and Low Eicosapentaenoic Acid Level with In-Stent Restenosis in Patients with Acute Coronary Syndrome. J Atheroscler Thromb., 2019; 26(3): 272-281. 
36. Briguori C, Quintavalle C, D'Alessio F, Donahue M, Roscigno G, De Micco F, Focaccio A, Visconti G, Del Vecchio L, Madonna R, De Caterina R, Condorelli $\mathrm{G}$, Impact of statin therapy intensity on endothelial progenitor cells after percutaneous coronary intervention in diabetic patients. The REMEDY-EPC late study. Int J Cardiol., 2017; 244: 112-118.

37. Johnson C, Waters DD, DeMicco DA, Breazna A, Bittner V, Greten H, Grundy SM, LaRosa JC, Comparison of effectiveness of atorvastatin $10 \mathrm{mg}$ versus $80 \mathrm{mg}$ in reducing major cardiovascular events and repeat revascularization in patients with previous percutaneous coronary intervention (post hoc analysis of the Treating to New Targets [TNT] Study). Am J Cardiol., 2008; 102(10): 1312-1317.

38. Pasceri V, Patti G, Nusca A, Pristipino C, Richichi G, Di Sciascio G, Randomized trial of atorvastatin for reduction of myocardial damage during coronary intervention: results from the ARMYDA (Atorvastatin for Reduction of MYocardial Damage during Angioplasty) study. Circulation, 2004; 110 (6): 674-678.

39. Tsukie N, Nakano K, Matoba T, Masuda S, Iwata E, Miyagawa M, Zhao G, Meng W, Kishimoto J, Sunagawa K, Egashira K, Pitavastatin-incorporated nanoparticleeluting stents attenuate in-stent stenosis without delayed endothelial healing effects in a porcine coronary artery model. J Atheroscler Thromb., 2013; 20(1): 32-45.

40. Wang Y, Qiao Z, Lu T, Li K, The efficacy of coenzime Q10 în combination with atorvastatin on coronary heart disease. Farmacia, 2020; 68(3): 547-552.

41. Putzu A, de Carvalho E Silva CMPD, de Almeida JP, Belletti A, Cassina T, Landoni G, Hajjar LA, Perioperative statin therapy in cardiac and non-cardiac surgery: a systematic review and meta-analysis of randomized controlled trials. Ann Intensive Care, 2018; 8(1): 95: 1-14. 